\title{
The New Economy Is Dead, Long Live the Information Economy
}

Phillip J. Bryson

phil_bryson@byu.edu

Follow this and additional works at: https://scholarsarchive.byu.edu/facpub

Part of the Economics Commons

\section{Original Publication Citation}

The New Economy is Dead, Long Live the Information Economy, Intereconomics: Review of European Economic Policy, Volume 38, Issue No. 5, September, 23, pp. 276-282.

http://www.springerlink.com/content/yx8t7g5334k244/ http://www.intereconomics.eu/archiv/ suche.php

\section{BYU ScholarsArchive Citation}

Bryson, Phillip J., "The New Economy Is Dead, Long Live the Information Economy" (2003). Faculty Publications. 481.

https://scholarsarchive.byu.edu/facpub/481 


\title{
Phillip J. Bryson* \\ The New Economy Is Dead, Long Live the Information Economy
}

\begin{abstract}
The arrival of the 2001-2003 recession caused many to suppose that the so-called "New Economy" was now defunct. This article addresses a number of related issues, including the question of the durability and viability of business cycles in the face of the technological developments of the information age. It asks what went wrong with the New Economy and examines its characteristics as well as its remaining possibilities and prospects for the future. Finally, it considers the spread of the Information Economy to Europe, especially to Germany, the country that one might expect to be the leading European player, but which is not at present actually a strong competitor for that role.
\end{abstract}

$\mathrm{D}$ esignation of the economic developments of recent years as the "New Economy" was probably counterproductive. To some the New Economy was simply the new technology sectors of the economy. The crash of the NASDAQ and the closing of the neuer Markt in Germany gave rise in some quarters to the notion that the New Economy had become defunct.

The New Economy meant different things to different people, but generally included the following elements:

- the belief that recessions had been overcome and that stock prices, which had actually become bubble prices, represented legitimate possibilities for future wealth, i.e. the actual present value of firms;

- the productivity revival that occurred in the United States mostly in the second half of the 1990s;

- the ascension of knowledge roughly to the level of a factor of production, and the development of information and communications technologies to an extent that makes all sectors of the economy more productive;

- the institutional changes that were necessary for the firm's accommodation to the digital economy, the organization of the firm, the nature of industrial competition etc., which are transforming commerce, the economy, and society.

The first item proved an illusion with the arrival of the 2001-2003 recession, which caused many to suppose that the New Economy was now defunct. Actually, it only proved that that particular misconception is now defunct; it had been rejected by many before the recession arrived. ${ }^{1}$ None of the other propositions have really been changed by the recession. Those who tend to believe that these phenomena are neither chimerical nor transitory, nor restricted to a small number of select industries, are beginning to favor different

* Douglas and Effie Driggs Professor of Economics, Brigham Young University, Provo, Utah, USA. rubrics. "The New Economy," which in any case is no longer so new, should now give way to rubrics like "the information economy."

This article shares the view of most of those producing the literature addressing these issues, viz., that information and communications technologies (ICT) have irrevocably changed the US economy and a small number of additional economies. In time it can change others as well. The macro economy must of course still deal with the decisions and actions of the aggregate of micro agents, and we have all seen the evidence that despite new, information age technologies, this cannot yet be done in a manner that eliminates the cycle.

This paper will first address the questions whether there has been, whether there is, and whether there will be what we have called a "New Economy." It will review the core issues and the views of those qualified to tell us what a new economy might be. It will then turn, hopefully for the last time, to the question of the durability and viability of business cycles in the face of the technological developments of the information age. Next it will ask what went wrong with the New Economy and consider its characteristics as well as its remaining possibilities and prospects for the future. Finally, it will consider the spread of the Information Economy to Europe, especially to Germany, the country that one might expect to be the leading European player, but which is not at present actually a strong competitor for that role.

\section{Impact on Productivity Growth}

A rapid decline in the prices of computers and other information and communications equipment in recent years has permitted a dramatic diffusion of computer-based technologies. This resulted not in technical change creating greater output from the same inputs,

${ }^{1}$ P. J. Bryson: Economy and "New Economy" in the United States and Germany, in: INTERECONOMICS, Vol. 36, No. 4, July/August 2001, pp. 180-190.

Intereconomics, September/October 2003 
but in massive substitution of computers in home use and in the business sector for other types of equipment and for labor. ${ }^{2}$ Normally, capital equipment results in "spillovers" which appear in econometric studies as "residual" economic growth after that attributable to capital and labor is taken into account.

Over the period from 1948-1973, output grew at the rate of $3.4 \%$ per year, of which capital and consumers' durables produced $43 \%$, while labor produced $32 \%$ of the total growth. Total factor productivity accounted for the remaining $25 \%$. But output growth slowed dramatically after 1973 , and again less markedly after 1990 , reducing the rate of output growth a full percentage point - to $2.4 \%$ per year - from 1990 to 1996. It should be observed here that computers have contributed to growth not only as an investment good, but also through a "service flow" to households. Since 1990, according to Jorgenson and Stiroh, computers contributed nearly a sixth of the annual $2.4 \%$ output growth: they represented approximately $20 \%$ of the contribution of capital inputs to growth and $14 \%$ of the contribution of consumers' durables services.

There is no question that computer-related gains are changing the economy in a fundamental way. They are not doing so, however, by producing growth spillover effects to the economy as a whole. Rather, returns to the economy's investments in IT equipment have been captured by computer producers and users themselves as they substitute this equipment for other inputs.

It does appear that the "New Economy" could have produced an increase in the productivity of the American economy. Since the middle of the seventies that productivity had clearly slowed down, prohibiting a growth of incomes. But it was expected that the introduction of new technologies, especially in information processing and telecommunications, could reverse this trend. Naturally, there is usually a lag between the implementation of new technologies and the appearance of productivity effects. Heileman et.al. ${ }^{3}$ show that the quarterly productivity rates since about 1995 do in fact seem to indicate an upward shift in the trend. The time period in question is a brief one, so that New Economy skeptics have doubted whether the rather dramatic increases will be sustained. There have been periods of increasing productivity in the past, especially in the last phases of cyclical upturns, which did

2 D. W. Jorgenson, K. J. Stiroh: Information Technology and Growth, in: American Economic Review, Vol. 89, No. 2, 1999, pp. 109-115.

${ }^{3}$ U. Heilemann, R. Döhrn, H. D. von Loeffelholz, E. SchäferJäckel: Der Wirtschaftsaufschwung der Vereinigten Staaten in den neunziger Jahren - Rolle und Beitrag makroökonomischer Faktoren, Essen 2000, Rhine-Westphalia Institute for Economic Research (RIW), p. 36 .

Intereconomics, September/October 2003 after a time prove to be strictly temporary. We need to look carefully at that brief period and beyond it.

American firms invested at a remarkable pace in information technologies, with investments in computers and peripheral equipment increasing more than four-fold between 1995 and 1999. Output per labor hour increased at approximately $2.5 \%$ annually between 1995 and 1999. In this period, the contribution of IT capital to output growth increased dramatically, nearly doubling to 1.1 percentage points. Information technology capital assumed greater importance in the economy and there was more rapid growth of the real stocks of computer hardware and communications equipment. ${ }^{4}$

Jorgenson ${ }^{5}$ has attributed the resurgence of American productivity growth to the spectacular development and deployment of semiconductors. Heavy investments in IT products have reflected an amazing decline in IT prices, which has in turn been a product of the development of semiconductor technology. It is encouraging that Jorgenson could report that semiconductor prices are projected to continue to decline for another decade at least.

Jorgenson indicates that the most important source of US economic growth throughout the postwar period has been capital input. But since 1995 the contribution of that factor has accelerated economic growth by nearly a full percentage point, with the IT contribution accounting for over half of that increase. As Jorgenson retraces the development of the semiconductor phenomenon one reviews with him a set of technological achievements producing structural rather than cyclical changes in the economy. When he finds it premature to extrapolate the productivity growth of the relatively recent past for these industries into the indefinite future, he declines to do so because that growth is dependent on the persistence of a two-year product cycle for semiconductors. This, of course, is what underlies the growth of IT capital services, which increased from $11.51 \%$ annually from 1990-1995 to 19.41 in the second half of the decade. Growth of non-IT capital services increased from the first to the second half of the decade, increasing from $1.72 \%$ to $2.94 \%$, reversing the trend toward slower capital growth through 1995.

The ICT skeptic, respected and cited by his colleagues in the field, is Robert Gordon. Baily, ${ }^{6}$ for example, like most of his colleagues, attributes a large

${ }^{4}$ S. D. Oliner, D. E. Sichel: The Resurgence of Growth in the Late 1990s: Is Information Technology the Story?, in: Journal of Economic Perspectives, Vol. 14, No. 4, 2000, pp. 3-22.

${ }^{5}$ D. W. Jorgenson: Information Technology and the U.S. Economy, in: American Economic Review, Vol. 91, No. 1, 2001, pp. 1-32.

${ }^{6}$ M. N. Baily: The New Economy: Post Mortem or Second Wind?, in: Journal of Economic Perspectives, Vol. 16, No. 2, 2002, pp. 3-22. 
boost in labor productivity to rapid accumulation of information technology capital, as well as from faster multifactor productivity within the information technology sector. But Baily feels the necessity of addressing counterarguments raised by Gordon.

The latter argues that faster labor productivity growth, appropriately adjusted for cyclical effects, is the result merely of faster multifactor productivity growth in the IT sector itself and in the rest of durable manufacturing. ${ }^{7}$ But the IT sector and durable manufacturing together constitute only approximately $12 \%$ of the private economy. Moreover, Gordon holds that during the boom of 1995-2000 even many of the New Economy optimists could perceive that output growth was running at a faster pace than the sustainable long-term growth trend. Therefore, according to Gordon the productivity growth was largely a cyclical phenomenon. He still wonders to what extent the ITC industries represent fundamental new technologies, completely transforming industrial production processes and making fundamental changes in the organization of the firm and its labor relations. ${ }^{8}$

Oliner and Sichel ${ }^{9}$ emphasize that the crucial difference between Gordon's work and their own is his focus on trend productivity growth while their work addresses developments in actual productivity growth. These authors also cite the work of Whelan ${ }^{10}$ and Jorgenson and Stiroh ${ }^{11}$ as giving results similar to their own.

Baily and Lawrence ${ }^{12}$ reject Gordon's interpretation of the productivity growth of the late 1990s. Like other experts, they cite research results more compatible with their own, in this case the work of Sharpe. ${ }^{13}$ They argue that the substantial structural acceleration of total factor productivity outside the IT sector proper and the clear evidence of productivity acceleration in those service industries heavily purchasing IT equipment certainly verify the existence of a new economy.

${ }^{7}$ R. J. Gordon: Does the "New Economy" Measure up to the Great Inventions of the Past?, in: Journal of Economic Perspectives, Vol. 14, No. 4, 2000, pp. 49-74.

${ }^{8}$ Rhine-Westphalia Institute for Economic Research (RIW) and R. J. Gordon: New Economy - An Assessment from a German Viewpoint, Essen 2001

${ }^{9}$ S. D. Oliner, D. E. Sichel, op. cit.

${ }^{10} \mathrm{~K}$. Whelan: Computers, Obsolescence, and Productivity, Federal Reserve Board, Finance and Economics Discussion Series Paper, February 2000.

${ }^{11}$ D. W. Jorgenson, K. J. Stiroh: U.S. Economic Growth in the New Millennium, in: Brookings Papers on Economic Activity, No. 1 2000, pp. 125-211.

12 M. N. Baily, R. Z. Lawrence: Do We Have a New E-conomy?, in: American Economic Review, Vol. 91, No. 2, 2001, pp. 308-312.

${ }^{13}$ A. Sharpe: The Productivity Renaissance in the U.S. Service Sector, in: International Productivity Monitor (Center for the Study of Living Standards, Ottawa, Canada), No. 1, Fall 2000, pp. 6-8.
These authors observe that labor productivity accelerated by 1.6 percentage points in the second half of the nineties and that their estimates suggest the cycle had nearly no impact on the period's productivity growth, implying a structural acceleration of productivity for the period.

The productivity resurgence of the nineties reflects both the production and the use of IT. ${ }^{14}$ Econometric tests of a wide variety demonstrate a strong correlation between IT accumulation and labor productivity development, and Stiroh finds that all of the aggregate productivity acceleration can be traced to industries producing or using IT intensively. He alludes to Gordon's work and the assertion of the latter that, except for cyclical effects, the recent productivity acceleration is otherwise concentrated in the relatively small share of the economy engaged in the production of IT and other durable goods.

Baily's work ${ }^{15}$ is rather destructive of Gordon's casual observation that computers have been around for almost 50 years and that the main productivity gains they had to offer have already been experienced. This betrays a lack of sensitivity for the sweeping changes that computers have made and are yet capable of, since it takes time to perceive their possibilities, implement the intangible organizational adjustments that enhance their operation, and secure the full effects of the information revolution, most of which go far beyond numerical computation. These are the reasons why Baily insisted that IT was not the sole reason for the productivity revival of the later nineties.

He observes that a growth accounting framework making use of both income and product data indicates a significant increase in multifactor productivity growth after 1995 outside the IT hardware sector. Moreover, when one reviews case studies of individual industries, one cannot ignore evidence that innovative business practices accompanying, although sometimes unrelated to information technology, have contributed in important ways to increased productivity.

Baily also relates productivity growth to the competitive intensity of particular industries, because intensive competition increases static efficiency by driving out slack management practices, promotes the entrance of high productivity enterprises and the exiting of low productivity enterprises from the market, and encourages innovation on the part of companies competing to survive.

But what of the future, now that the euphoria of the late 1990s has ended and the recession has arrived?

\footnotetext{
${ }^{14}$ K. J. Stiroh: Information Technology and the U.S. Productivity Revival: What Do the Industry Data Say?, Federal Reserve Bank of New York, January 24, 2001.

${ }^{15}$ M. N. Baily, op. cit.
} 
Will the post-1995 productivity revival continue? Baily's "basic drivers" of productivity acceleration - rapid improvements in information technology, strong competition and the impact of globalization - are still in place for the productivity growth revival to continue, and this is generally his expectation and that of other specialists.

Although perceptions as to the drivers of productivity growth differ, Baily interprets the literature to anticipate a near term productivity trend which will likely run from 2 to $2.7 \%$ per year. That level of productivity growth would permit GDP expansion at a rate of 3.0 to $3.7 \%$ per annum. The important shift in the US economy of the 1990s can be expected to continue with productivity growth remaining strong. That, of course, does not imply a return to the late-1990 economic euphoria.

\section{Macroeconomic Stability}

The euphoria postulate of the "new economic boom" was that business cycles had been overcome. The arrival of the recession should not make us dismiss this hope with a snicker rather than a retrospective consideration, since Zarnowitz ${ }^{16}$ presented for evaluation some interesting arguments that were adduced to make the case that the environment of that period contained elements that would discourage if not stave off recessions. Zarnowitz himself saw some of the arguments as dubious, although several of them together might indeed contribute to greater macro stability.

Alas, the arrival of the recession brought new lessons. These arguments included, inter alia, the notion that downsizing and rationalization processes had increased the economy's stability, although effective downsizing and cost-cutting would increase productive efficiency and permit later growth and "upsizing."

Improved inventory control, particularly through just-in-time management techniques was alleged to have increased stability. But Zarnowitz observed that constant dollar inventory investments in the 1990s had remained about as "volatile and as cyclical" as in the past.

The growth of the service economy was thought to contribute to stability, since it was less volatile than the manufacturing and construction industries which were in decline. But it was no less apparent in the nineties that the growing international competition in services would likewise render them more cyclical. Meanwhile, the deregulation of financial and other industries probably added stability and greater competition in airlines, trucking, banking, etc., likely enhanced productivity

\footnotetext{
${ }^{16}$ V. Zarnowitz: Theory and History Behind Business Cycles: Are the 1990s the Onset of a Golden Age?, in: Journal of Economic Perspectives, Vol. 13, No. 2, 1999, pp. 69-90.
}

growth. But it is unlikely that further deregulation will promote further stability.

Discretionary macro policies, shifting the emphasis for control to interest-rate adjustments have been effective in the absence of less-suitable fiscal policies. But policies cannot always anticipate and avert recessions or financial crises, and policies can be misguided, mistimed, or bungled. And we have learned how little help even astute policies can render in the face of an investor confidence crisis stemming from systematic presentation of misleading and falsified corporate financial information.

Globalization may well reduce instability as healthy foreign markets reduce our dependence on domestic consumers. Imported resources and products reduce inflationary pressure in domestic markets. Globalized capital markets are broader and more liquid, offering the potential of reducing the risk of market bubbles and crashes. But now, as a recession mentality distorts our view of the future's possibilities, it may be just as shortsighted to hold our gaze away from realistic and promising possibilities of the information age. The miscalculations, excesses, over-reactions, and zealous retrenchments that are yet a persistent part of human commerce may dim the promise of our possibilities from time to time, but we can continue to trust that reason and rationality will ultimately restore us to more favorable trends.

The most important thing that can be observed about the business cycle here is that the current recession will not end the productivity revival of the late nineties. This is, at least, the consensus of the productivity analysts referred to above. Baily, ${ }^{17}$ for example, defying the uncertainty that affects predictions of productivity, expresses the conviction that strong productivity growth will likely resume with economic recovery.

Oliner and Sichel ${ }^{18}$ see the growth contribution from IT investments remaining comparatively strong "for at least the next few years." Baily and Lawrence ${ }^{19}$ argue that an interpretation of the collapse of many dot.coms as the disappearance of the new economy "is a misreading of what has happened." They find that the commercial application of the internet only recently became important and wasn't the main source of productivity revival in the 1990s. But the internet will be even more important in the future, reducing the costs of communications and transactions, especially benefiting small companies. Litan and Rivlin ${ }^{20}$ estimate that the Internet will add between 0.25 and 0.5

\footnotetext{
${ }^{17}$ M. N. Baily, op. cit., p. 3.

${ }^{18}$ S. D. Oliner, D. E. Sichel, op. cit., p. 21.

${ }^{19}$ M. N. Baily, R. Z. Lawrence, op. cit., p. 311.
} 
percentage points per year to future growth. Finally, at a conference at the Atlanta Federal Reserve Bank, Jorgenson and Stiroh argued that productivity growth over the next decade will remain a robust $2.24 \%$ annually. ${ }^{21}$

These conclusions rest on technical analyses of the impact of ICT on productivity growth. They are not a forecast about cycles, although a prolonged recession could impact productivity growth by causing an extended postponement of ICT along with other investments. Even if it does so, the end of the recession would herald a renewal of productivity growth, since the impacts of information and communication technologies on commerce, the economy, and society will continue for years to come as indicated by the findings documented in this paper.

\section{What Went Wrong?}

To inquire what went wrong with the New Economy is to ask the wrong question. It assumes again that the New Economy included the provision that the cycle had been consigned to the trash heap of history. The arrival of recession merely indicates that that particular conception of the New Economy was erroneous.

It wasn't so much that the New Economy did anything wrong as that some of the early dot.coms did. In a sense, that conception and the misguided thinking that accompanied it in some quarters were in fact a problem for the New Economy. It was a problem that participants based their actions not on carefully crafted strategies, but on vague "first mover" hopes and the pursuit of market share through "introductory" pricing. These mistakes sometimes proved disastrous both for the foolhardy and sometimes even for those of greater prudence caught in an irrational environment. ${ }^{22}$ Such low-price strategies, common to neophyte competitors in the fruitless price wars of some unfortunate young industries, have had significant presence on the Internet landscape. The omnipresent hope of early dot.com experience was that price discrimination would be facilitated by ecommerce where sellers could retain and readily access detailed information about the buying habits of their customers. But that prospect is undermined to the extent that the customer uses the internet adroitly to find the best price available.

Porter $^{23}$ has written persuasively about the folly of using internet technology to shift the competitive

${ }^{20}$ R. E. Litan, A. M. Rivlin: Projecting the Economic Impact of the Internet, in: American Economic Review, Vol. 91, No. 2, 2001, pp. 313-317.

${ }^{21}$ S. Liesman: Outlook, in: Wall Street Journal, July 7, 2002.

${ }^{22}$ S. Bornstein, G. Saloner: Economics and Electronic Commerce, in: Journal of Economic Perspectives, Vol. 15, No. 1, 2002, pp. 3-12. approach away from product quality, desirable characteristics, and service toward price. We have a case here of the new internet technology triggering rampant experimentation, with many companies subsidizing the purchase of their product hoping to secure a base of customers. In the same way, such subsidies have driven costs down for some firms purchasing on line, since suppliers are not only interested in attracting final consumers, but have also provided intermediate goods and services to dot.com buyers at heavily discounted prices.

Porter avers that the focus of the dot.coms was on the internet's potential to reach large numbers of consumers and the rapidity with which its use was increasing. Instead, the focus should have been on what impact its use would have on industry structure. Somehow, the internet was expected to unleash inexplicable forces that would ultimately generate industry profits. It would increase customer switching costs and strong network effects would translate into strong competitive advantages and down-the-road profitability for first movers. But the Internet hardly raised switching costs with the next seller a mere click away.

Too many ecommerce pioneers did not focus on profits, but pursued instead maximal revenues and market share at all costs through heavy advertising, giveaways, discounting, promotions, and channel incentives. Indirect revenues from advertising and click-through fees distracted their focus and effort, which should have been to deliver real value that earns a profitable price from customers as the firm adds unique value to the product for their buyers.

\section{Remaining Possibilities and Prospects}

But electronic computation and communication capacities can also be properly used, and the New Economy is also worthy of attention for the right things it did and remains capable of doing. Brynjolfsson and $\mathrm{Hitt}^{24}$ remind us, for example, that computers add value not only in the area of numerical calculation. It is their symbol processing capacity, as opposed to their number crunching capacity, that will cause computer applications to produce complementary innovations far into the future. IT encourages complementary organizational investments in business processes, enabling cost reductions and increased output quality. Such quality includes new products, improvements in difficult-to-measure product characteristics such as variety, convenience, timeliness and quality.

${ }^{23}$ M. E. Porter: Strategy and the Internet, in: Harvard Business Review, March 2001, pp. 63-78.

${ }^{24}$ E. Brynjolfsson, L. M. Hitt: Beyond Computation: Information Technology, Organizational Transformation and Business Performance, in: Journal of Economic Perspectives, Vol. 14, No. 4, 2000, pp. 23-48.

Intereconomics, September/October 2003 
These authors also discuss a problem of IT that seems especially important to me. The difficulty of measuring the full impact with econometric methods results in my view in an understatement of the IT contribution to history. As well as Brynjolfsson and Hitt, Litan and Rivlin ${ }^{25}$ show part of the reason for this by discussing the aspects of IT contributions not easily captured by the traditional growth accounting techniques. Intangible characteristics that improve quality, change product characteristics and quality as embodied in new products, improved service for the consumer, and the speed associated with all facets of transaction and ownership are not captured in the usual quantitative evaluations. In the same way, traditional measurement focuses on the measurable aspects of investment, e.g. the prices and quantities of IT products, while neglecting even larger intangible investments in developing complementary new products, services, and markets, internal business processes and organizational adaptations, and in developing requisite labor and management skills. A study by Brynjolfsson and Yang ${ }^{26}$ of 800 firms showed that the value of the intangible assets associated with information technology investments may be 10 to 1 . Consequently, an investment of $\$ 167$ billion in computer capital in 1996 US national accounts may have been the more apparent share of a total investment by industry of $\$ 1.67$ trillion.

Litan and Rivlin ${ }^{27}$ also make an important point in demonstrating how much the internet adds to the value enjoyed by producers and consumers. It reduces transactions costs in the distribution of commodities and consumers, it increases management efficiency, especially in facilitating more effective communications and supply chain management, and increases competition, especially by rendering prices more transparent.

Their vision of an internet revolution foresees a gradual transformation of the international market system, increasing competition, reducing profit margins, enhancing productive efficiency and generating greater consumer satisfaction. Litan and Rivlin note that specific sectors of the economy, such as health care and other services, will become much more productive through the internet. Extrapolating from a modest sampling of firms in each sector they estimate roughly that the internet enables a total cost saving from \$100230 billion annually.

\footnotetext{
${ }^{25}$ R. E. Litan, A. M. Rivlin, op. cit.

${ }^{26}$ E. Brynjolfsson, S. Yang: The Intangible Benefits and Costs of Computer Investments: Evidence from Financial Markets, in: Proceedings of the International Conference on Information Systems, Atlanta, GA, 1997, Revised 2000.

${ }^{27}$ R. E. Litan, A. M. Rivlin, op. cit., p. 314.
}

Intereconomics, September/October 2003

\section{ITC Development in Europe}

Europe got a later start in the development of ICT than did the United States. Although fewer individuals and households became a part of the information revolution, and firms and governments failed to see helpful computer applications as quickly in Europe, the changes started to develop there with only a short lag. Naturally, development in some European countries outpaced that experienced across national boundaries. The northern countries were quick to pursue acquisition of the new technologies, but France, Germany, Italy, and Spain followed at some distance; there were more pressing concerns in the era of most significant ICT development, such as the construction of monetary union and the reunification of Germany.

Germany was at first doubtful whether New Economy productivity growth was real; Robert Gordon became the academic father of German skepticism about the productivity boom, but officials saw the important possibilities in ecommerce and egovernment. German households ultimately pursued DSL hookups in greater numbers than did other Europeans.

For Europe of the 1990s, spending on hardware and software, on communications and other IT services was not fully $6 \%$ of GDP. US expenditures amounted to roughly $8 \%$ of GDP. ITC investments in the EU were $2 \%$ of GDP and in the US nearly $3.5 \%$. The gaps in both spending and investment between the EU and the Unites States have actually risen over time. ${ }^{28}$

It is more descriptive to say that the IT gap is not an EU, but a national phenomenon, affecting some but not all European countries. IT development in Sweden, the Netherlands, and the UK is quite similar to that of the United States, and Ireland has enjoyed returns on IT investment (with a high TFP contribution from IT production), although the four large Union countries mentioned previously lag behind northern Europe.

By 2001, IT spending had reached 0.8 trillion USD by the US and 0.5 trillion by Europe, roughly $38 \%$ and $24 \%$ of the world IT market respectively. ${ }^{29}$ Europe's share of the world IT market is smaller than its share in world GDP, but the US share of the world IT market exceeds its share in world GDP. Here again, Europe's gap is growing: while the EU share of world GDP declined by five percentage points in seven years, its share of global IT expenditures declined by nearly eight points. Both figures increased for the United States, but even more so in the case of IT spending shares.

In 1999, at the height of the US boom, IT expenditures for both Sweden and the UK represented a larger

${ }^{28}$ F. Daveri: Information Technology and Growth in Europe, University of Parma, and IGIER, May 10, 2001.

${ }^{29}$ lbid., p. 8. 
portion of their GDP than those of the US did. The Netherlands, Denmark and Ireland also spent more on IT than the EU average, with Finland and Belgium not far behind. This large national diversity is the target of EU policies, designed to make Europe more competitive in the development of information and communications technologies.

On the one hand, the EU is concerned that the contribution of computers to economic growth, although sizeable, has generally been relatively smaller than that contribution in the US. On the other hand, Europe is reassured that the contribution to growth of communications equipment was relatively higher than in the US.

The European Union has addressed the lag in ITC development by preparing an action plan ${ }^{30}$ with targets for 2005, at which time it expects to see modern online public services, egovernment, elearning services, and ehealth services. At the heart of the information environment will be a dynamic ebusiness system, all of which will be enabled by general availability of competitively priced broadband access and a secure information infrastructure.

The EU is quick to emphasize the accomplishments of the year 2002, which saw internet penetration in individual households double, the telecom framework in place, internet access prices falling, nearly all companies and schools connected, the legal framework of ecommerce basically in place, the world's fastest "research backbone network" established, and the emergence of a smartcard infrastructure underway. Clearly, public support undergirds ITC development. The comparative development of the EU and the US will be a matter of supportive public institutions and financial support, and the encouragement of private initiative. In the meantime, it is reported that, in part due to the recession in the US and in part due to an increase of European investments, Europe has recently matched the US in the past year's share of GDP devoted to IT investments.

\section{Conditions in Germany}

Germany is reluctant to view its position as "limping along behind" (Hinterherhinken), but attributes different ICT developmental patterns to different economic developments and experience. ${ }^{31}$ In the nineties, the US enjoyed stronger pre-conditions for the adoption and diffusion of information and communications technologies, due to the German preoccupation with

${ }^{30}$ Commission of the European Communities: eEurope 2005: An information society for all. An Action Plan to be presented in view of the Sevilla European Council, 21/22 June 2002. See http://europa.eu.int/ information_society/eeurope/news_library/documents/eeurope2005/ eeurope2005_en.pdf.

${ }^{31}$ Rhine-Westphalia Institute for Economic Research (RIW) and R. J. Gordon, op. cit. reunification. Moreover, the structural reforms undertaken by US industry in the eighties in preparation for the boom of the nineties had to be instigated by Germany in the nineties.

Development of the more productive information economy is seen as essential by Germany. Confronting an aging population and a declining rather than growing population, the only path to economic growth and rising incomes in the long run can be through a permanent and unswerving application of technical and organizational progress. A substantial contribution will have to come from ICT and it is seen as the task of federal and local governments to provide the essential organizational and institutional framework. To establish such a framework, the German government intends to restructure schools and university education, strengthening the interaction of research universities, government research grants, and private industry. It is recognized that there must be greater flexibility in markets through privatization of state-owned enterprises, the establishment of more ready access to markets, the elimination of industrial regulations that have outlived their usefulness, and the provision of an appropriate physical and financial infrastructure for new start-ups and the internal growth of German firms. Some commentators on this issue are relatively pessimistic whether the enabling German spending on ICT will actually produce the desired productivity enhancement in the current economic environment. ${ }^{32}$ The competitive conditions and institutional flexibility is simply wanting in the Federal Republic at this point in time.

Being a follower is not always disadvantageous of course, and Germany will benefit by having observed some of the problems strewn along the way in New Economy history. Germans are fully aware of the intense, sometimes foolishly intensive price competition in the dot.com boom referred to above. ${ }^{33}$ Naturally, the on-line information on commodity and service supplies available to consumers will increase competition among suppliers, which in turn tends to promote falling prices and increased productivity. Price competition of this sort is not enthusiastically embraced by German firms, or sometimes even consumers, but they are part and parcel of the information economy. Gradually, there will be some accommodation in German attitudes to Information Economy conditions, but there will also be a differentiated approach to the whole question of internet competition in that country.

32 P. Kalmbach: "New Economy" - war da was?, in: Wirtschaftsdienst, Vol. 83 , No. 1, 2003, pp. 38-44; H. Krämer: Was bleibt von der New Economy? in: WSI Mitteilungen, No. 12, 2002, pp. 728-735.

${ }^{33}$ W. Larmann, W. Matthes: Thema: New Economy, in: Wirtschaft und Unterricht: Informationen für Pädagogen in Schule und Betrieb, Vol. 27, No. 3, 2001, pp. 1-4.

Intereconomics, September/October 2003 